\section{JURNAL ABDIMAS

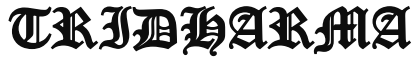 \\ AtA:}

P-ISSN 2615-6849, E-ISSN 2716-070X

Jurnal ABDIMAS Vol. 2,No.3,Agustus 2021,Hal(18- 25)

@ Prodi Manajemen Fakultas Ekonomi Universitas Pamulang

Email: abdimasjurnal.unpam@gmail.com Telp: (021) 741-2566

\title{
PENYULUHAN PENGELOLAAN KEUANGAN USAHA KECIL MENENGAH PADA UKM MERTA YASA BALI
}

\author{
Muliahadi Tumanggor, Bulan Oktrima, Rr. Ayu Metarini, Jamaludin, Ali Zaenal Abidin \\ Dosen Prodi Manajemen Fakultas Ekonomi Universitas Pamulang \\ Email : dosen00871@unpam.ac.id, dosen00790@unpam.ac.id, dosen00945@unpam.ac.id, \\ dosen01020@unpam.ac.id, dosen00864@unpam.ac.id
}

\begin{abstract}
ABSTRAK
Pengabdian Kepada Masyarakat (PKM) merupakan salah satu darma dari tri dharma perguruan tinggi, maka dari itu melakukan PKM merupakan suatu keharusan bagi Dosen minimal 1 kali dalam satu semester. Dengan demikian, pada kesempatan ini Tim Dosen Prodi Manajemen Unpam melakukan PKM pada UKM Merta Yasa, Bali. Dengan sasarannya adalah pengusaha Usaha kecil menengah. adapun tema yang diangkat adalah "Penyuluhan Pengelolaan Keuangan Usaha Kecil Menengah Pada Ukm Merta Yasa, Bali". Perekonomian suatu negara sangat bergantung dengan usaha yang dilakukan oleh warganya. Beberapa pengusaha mulai dengan modal kecil atau menengah. Dengan bantuan Pemerintah, usaha UKM dapat berkembang pesat.

Usaha mandiri yang bisa diupayakan pengusaha UKM, adalah memilih jenis usaha yang populer dan strategi pengembangan yang jitu. UKM adalah jenis bisnis yang dijalankan dengan skala kecil dan menengah dan bukan anak perusahaan atau cabang perusahaan mana pun. Jadi secara tidak langsung pengertian UKM adalah usaha kecil memiliki pemasukan di bawah 300 juta dengan jumlah pekerja di bawah 20 orang. Sedangkan usaha menengah dengan pemasukan di bawah 500 juta dengan jumlah karyawan di bawah 30 orang. Masalah utama yang sering terjadi dalam tata kelola keuangan UKM, yaitu tidak ada perencanaan kas, penghasilan selalu habis untuk dibelanjakan, minimnya pengetahuan dan keterampilan manajemen keuangan.

Hasil kegiatan menunjukkan bahwa terjadi peningkatan kemampuan para peserta dalam manajemen keuangan UKM, peningkatan kerampilan dalam perencanaan dan pengelolaan kas, dan peningkatan dalam pengelolaan keuangan.
\end{abstract}

Kata kunci: Manajemen Keuangan, Pengelolaan Keuangan, Usaha Kecil Menengah.

\section{ABSTRACT}

Community Service (PKM) is one of the principles of the Tri Dharma of Higher Education, therefore conducting PKM is a must for Lecturers at least once a semester. Thus, on this occasion the Unpam Management Study Program Lecturer Team conducted PKM at Merta Yasa UKM, Bali. With the target is small and medium business entrepreneurs. as for the theme raised was "Counseling on Financial Management for Small and Medium Enterprises at SMEs Merta Yasa, Bali". The economy of a country is very dependent on the efforts made by its citizens. Some entrepreneurs start with small or medium capital. With the help of the Government, SME businesses can grow rapidly.

Independent businesses that can be pursued by SME entrepreneurs are choosing popular types of businesses and accurate development strategies. SME is a type of business that is run on a small and medium scale and is not a subsidiary or branch of any company. So, indirectly, the meaning of SMEs is that small businesses have an income of below 300 million with a number of workers under 20 people. Meanwhile, medium-sized businesses with an income of less than 500 


\section{JURNAL ABDIMAS

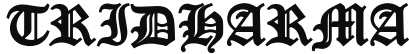 \\ AIA}

P-ISSN 2615-6849, E-ISSN 2716-070X

Jurnal ABDIMAS Vol. 2,No.3,Agustus 2021,Hal(18- 25)

@ Prodi Manajemen Fakultas Ekonomi Universitas Pamulang

Email: abdimasjurnal.unpam@ gmail.com Telp: (021) 741-2566

million have employees below 30 people. The main problems that often occur in the financial management of SMEs are no cash planning, income is always used up to be spent, lack of knowledge and skills in financial management.

The results of the activity show that there has been an increase in the participants' abilities in SME financial management, increased skills in cash planning and management, and improvements in financial management.

Keywords: Financial Management, Financial Management, Small and Medium Enterprises.

\section{PENDAHULUAN}

Pemberdayaan Masyarakat adalah upaya mengembangkan kemandirian dan kesejahteraan masyarakat dengan meningkatkan pengetahuan, sikap, keterampilan, perilaku, kemampuan, kesadaran, serta memanfaatkan sumber daya melalui serangkaian kebijakan, program, kegiatan dan pendampingan yang sesuai dengan esensi masalah dan prioritas kebutuhan masyarakat. Mendapatkan keuntungan yang besar setiap bulan tentu menjadi salah satu impian terbesar bagi setiap pebisnis. Karena dalam menjalankan bisnis, uang merupakan sebuah ujung tombak. Oleh sebab itu, pengelolaan uang yang bijak menjadi hal yang sangat penting demi kelangsungan bisnis. Jika uang tidak diatur secara cermat, maka pemasukan dan pengeluaran akan menjadi rancu. Bagi Anda yang sedang menjalankan sebuah bisnis, pastikan Anda telah memiliki strategi dan manajemen keuangan yang tepat.. Penerapan program ini ditempuh dengan cara pelatihan dengan metode studi kasus, latihanlatihan memecahkan masalah tentang Manajemen Modal Usaha dan Pengelolaan Kas.

Banyak orang beranggapan bahwa Manajemen keuangan keluarga merupakan salah satu bidang yang rumit. Sebenarnya manajemen keuangan keluarga tidaklah rumit seperti yang dibayangkan banyak orang, khususnya ibu-ibu yang sering di daulat sebagai manajer keuangan keluarga. Untuk menjadi manajer keuangan keluarga yang cerdas dan bijak, tidaklah harus menjadi seorang ahli keuangan.

Manajemen keuangan merupakan suatu proses dalam pengaturan aktivitas atau kegiatan keuangan dalam suatu bisnis. Termasuk kegiatan perencanaan, analisis, serta pengendalian terhadap kegiatan keuangan.

Selain itu, manajemen keuangan juga dapat diartikan sebagai seluruh aktivitas atau kegiatan bisnis yang berhubungan dengan upaya untuk mendapatkan dana perusahaan dengan cara meminimalkan biaya serta upaya penggunaan dan pengalokasian dana secara efisien dalam memaksimalkan nilai bisnis. Kegiatan keuangan tidak saja berlangsung pada bagian atau fungsi keuangan saja, tetapi juga pada bidang atau fungsi bisnis lainnya. Namun pada bidang keuangan, pada umumnya kegiatan keuangan lebih bersifat strategis. Berikut ini adalah kegiatan-kegiatan yang dilakukan oleh bagian keuangan:

1. Kegiatan pendanaan atau pembelanjaan. Bagian keuangan akan memikirkan bagaimana cara dan dari mana bisnis akan memperoleh dana.

2. Kegiatan investasi. Bagian keuangan akan memikirkan bidang-bidang investasi mana saja yang paling menguntungkan untuk menanamkan dana yang terkumpul dalam bisnis.

3. Kegiatan kebijakan dividen. Keuntungan dari kegiatan investasi selanjutnya akan dipertimbangkan oleh bagian keuangan. Apakah semuanya akan dibagikan kepada pemilik sebagai dividen atau ditahan semuanya untuk membiayai pertumbuhan dan perkembangan bisnis.

$$
\text { Hasil program PKM akan }
$$

disebarluaskan dalam bentuk artikel pada jurnal. Program PKM yang dilaksanakan ini diharapkan akan dapat menghasilkan luaran berupa: Peningkatan pengetahuan dan keterampilan manajemen keuangan dan peningkatan keterampilan dalam mangelola kas baik untuk kegiatan harian, mingguan dan bulanan,serta peningkatan pemahaman dan keterampilan dalam pengelolaan Kas Usaha. 


\section{JURNAL ABDIMAS

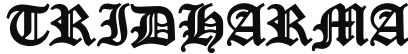

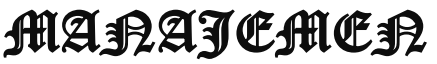

P-ISSN 2615-6849, E-ISSN 2716-070X

Jurnal ABDIMAS Vol. 2,No.3,Agustus 2021,Hal(18- 25)

@Prodi Manajemen Fakultas Ekonomi Universitas Pamulang

Email: abdimasjurnal.unpam@ gmail.com Telp: (021) 741-2566
Program dilaksanakan melalui Pengembangan pelatihan pada kegiatan Pengabdian Masyarakat, khususnya fokus pada bidang Manajemen Modal Usaha dan Pengelolaan Kas yang berkaitan dengan Pengelolaan Keuangan bagi pengusaha ukm dilaksanakan di Desa Blega kabupaten Gianyar dilaksanakan, Bali.

Pelatihan pengelolaan keuangan ini dipilih karena memiliki kelebihan yaitu berkaitan dengan aktifitas pengusaha UKM, juga mudah di implementasikan, murah dan ringan serta bersifat kekinian sehingga akan menarik perhatian para peserta yaitu ibu-ibu rumah tangga. Kolaborasi antara pelatihan dengan strategi kewirausahaan melalui usaha bisnis, dapat mendatangkan keuntungan sekaligus dapat dijadikan sebagai sarana penerapan hasil pelatihan secara langsung (Herdiana \& Kurniawan, 2017). Sementara program lainnya hanya memfokuskan pada program yang sejenis seperti program pelatihan saja (Irawan, 2016) atau program kewirausahaan saja (Andriani, Novianti, \& Fatati. 2014). Hal lain yang ditambahkan dalam kegiatan pengabdian masyarakat ini yaitu selain metode penlatihan yang dilakukan disertai adanya diskusi secara langsung dengan para peserta juga dilakukan penerapan perencanaan kas dan manajemen keuangan (dengan metode simulasi), sehingga para peserta merasa bahwa mereka benar-benar mengelola penghasilan yang fluktuatif.

Manajemen keuangan bukan hanya sebatas bagaimana sebuah usaha dapat mengelola kas, tapi bagaimana sebuah perusahaan mampu mengelola kekayaan untuk menghasilkan keuntungan dan memanfaatkan sumber-sumber modal tersebut untuk membiayai usaha. Meski sederhana, pengusaha kecil dan menengah perlu menerapkan prinsipprinsip manajemen keuangan.

Usaha Kecil Menengah atau UKM merupakan bisnis yang juga memerlukan pengelolaan keuangan yang baik. Setiap bisnis akan membutuhkan pengelolaan keuangan yang tepat agar bisnis tetap bisa berjalan dengan lancar. Maka PKM ini mengangkat sebuah tema "PENYULUHAN PENGELOLAAN KEUANGAN USAHA KECIL MENENGAH PADA UKM MERTA YASA, BALI"

\section{RUMUSAN MASALAH}

ini adalah:

Adapun rumusan masalah dalam PKM

1. Bagaimana Keuangan di UKM ?

2. Bagaimana Pengelolaan Keuangan di UKM?

3. Bagaimana pengusaha UKM dalam pengelolaan keuangan?

\section{TUJUAN KEGIATAN}

Adapun tujuan dari kegiatan pengabdian Kepada Masyarakat adalah:

1. Untuk mengetahui Keuangan di UKM.

2. Untuk mengetahui Pengelolaan Keuangan di UKM.

3. Untuk mengetahui pengusaha UKM dalam pengelolaan keuangan.

\section{TINJAUAN PUSTAKA}

\section{A. Manajemen keuangan}

Manajemen merupakan proses penting dalam suatu organisasi atau perusahaan. Dengan menggunakan manajemen yang baik, maka tujuan perusahaan dapat tercapai sesuai rencana yang ditetapkan. Menurut Malayu S.P. Hasibuan (2012) mengatakan bahwa manajemen adalah ilmu dan seni yang mengatur proses pemanfaatan sumber daya manusia dan sumber-sumber lainnya secara efektif dan efisien untuk mencapai tujuan tertentu

Pengertian keuangan adalah "Finance can be defined as the science and art of manging money", yang artinya adalah keuangan dapat didefinisikan sebagai seni dan ilmu pengetahuan dari pengelolaan uang. Sesungguhnya setiap individu dan organisasi menghasilkan uang dan membelanjakan atau menginvestasikan uang. Keuangan berhubungan dengan proses, institusi, pasar, dan instrument yang terlibat dalam perpindahan atau transfer uang antar individu, bisnis, dan pemerintah Gitman (2015:5).

Dari definisi keuangan tersebut maka dapat dikembangkan bahwa keuangan sebagai seni berarti melibatkan keahlian dan pengalaman. Sedangkan sebagi ilmu berarti melibatkan prinsip-prinsop, konsep, teori, proposi, dan model yang ada dalam ilmu keuangan yang mempelajari tentang bagaimana 


\section{JURNAL ABDIMAS

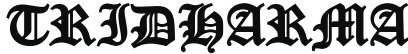

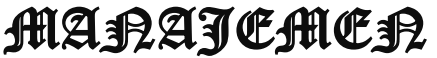

P-ISSN 2615-6849, E-ISSN 2716-070X

Jurnal ABDIMAS Vol. 2,No.3,Agustus 2021,Hal(18- 25)

@Prodi Manajemen Fakultas Ekonomi Universitas Pamulang

Email: abdimasjurnal.unpam@ gmail.com Telp: (021) 741-2566 pengelolaan uang, dimana keuanagan sangan berpengaruh dalam kehidupan setiap manusia.

\section{B. Memanajemen Keuangan UKM}

Rencanakan Penggunaan Uang, Sesuaikan rencana pengeluaran dengan targettarget penjualan dan penerimaan kas. Lakukan evaluasi terhadap rencana-rencana belanja yang menggunakan modal, jika tidak memberikan manfaat dalam meningkatkan penjualan atau menurunkan biaya-biaya. Lakukan analisa "cost and benefit" atau "untung-rugi" untuk meyakinkan bahwa penggunaan uang perusahaan tidak akan sia-sia dan memberikan return yang menguntungkan.

Perencanaan merupakan bagian penting dalam membangun perusahaan. Jika sudah direncanakan dengan matang, kemungkinan rugi akan lebih kecil. Tentunya perencanaan bagaimana produk terjual keras di pasaran juga harus diperhitungkan agar bisnis tidak merugi.

Buat Pencatatan Keuangan, Meskipun usaha UKM yang Anda miliki berada pada taraf sedang berkembang, namun untuk manajemen keuangannya tidak cukup dikelola berdasarkan ingatan, melainkan dengan catatan yang lengkap. Minimal, sebuah usaha wajib memiliki buku kas yang mencatat keluar masuknya uang. Lakukan pencocokan saldo dengan catatan keuangan usaha untuk mengontrol arus kas dan pastikan tidak ada perhitungan yang tertinggal.

Setiap transaksi harus dicatat dengan detail agar tidak terjadi kesalahan dalam pelaporan keuangan. Transaksi bisnis yang dicatat dengan tepat juga akan memudahkan proses perhitungan laba dan rugi. Setiap bukti transaksi akan menjadi catatan tentang berapa banyak produk yang terjual dan berapa keuntungan yang didapat.

Untuk membantu melakukan pencatatan keuangan, Anda dapat memanfaatkan Jurnal sebagai software akuntansi online. Dengan Jurnal, Anda hanya perlu mencatat seluruh transaksi usaha dan Jurnal akan menyediakan seluruh laporan keuangan yang bisa Anda dapatkan secara instan, mulai dari laporan arus kas, neraca, labarugi, perubahan modal, hingga laporan stok barang dan aset perusahaan.
Hitung Pembiayaan dengan Benar, Menghitung keuntungan dengan tepat sama pentingnya dengan menghasilkan keuntungan itu sendiri. Namun yang sering terlupakan dari penghitungan keuntungan ini adalah kesalahan terkait pengeluaran biaya yang dikeluarkan perusahaan. Jika perusahaan memiliki kesalahan pencatatan pembiayaan, maka secara tidak langsung hal ini akan berpengaruh pada kesalahan perhitungan keuntungan yang didapat. Terdapat tiga hal pembiayaan yang harus diketahui dan dihitung secara cermat, yaitu pembiayaan yang sedang terjadi, pembiayaan yang akan datang, dan pembiayaan akibat adanya penyusutan. Pencatatan pembiayaan yang dihitung secara cermat memudahkan pemilik usaha untuk mengontrol keuangan dan transaksi yang terjadi dalam sebuah bisnis.

Putar Arus Kas Lebih Cepat, Manajemen keuangan meliputi bagaimana Anda mengelola utang, piutang, dan persediaan barang dagangan. Banyak usaha mengalami kesulitan kas meski catatan akuntansi mereka menunjukkan angka yang bagus. Perhatikan perputaran arus kas, karena putaran kas akan melambat jika termin penjualan kredit ternyata lebih lama ketimbang masa restock atau penambahan barang dagangan. Seimbangkan perputarannya.

Lakukan Pengawasan Harta, Utang, dan Modal, Periksa persediaan di gudang secara berkala dan pastikan semuanya dalam keadaan lengkap dan baik. Buatlah sistem administrasi yang memadai untuk mengontrol hal tersebut. Lakukan hal yang sama terhadap piutangpiutang kepada pembeli dan tagihan-tagihan dari supplier. Jangan sampai terdapat tagihan macet atau pembayaran ganda kepada supplier tanpa sepengetahuan perusahaan. Buatlah pencatatan keuangan yang baik.

Gunakan Keuntungan untuk Kembangkan Usaha, Meskipun bisnis telah berjalan lancar bukan berarti semua keuntungan berhak digunakan di luar kepentingan usaha. Sebagai UKM, maka strategi manajemen keuangan yang penting adalah terkait pengembangan. Rencanakan investasi tambahan, kenali bidang-bidang yang masih menguntungkan dan dapat memperluas nilai aset perusahaan. Gunakan keuntungan secara 


\section{JURNAL ABDIMAS

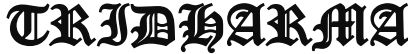

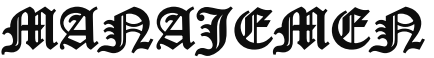

P-ISSN 2615-6849, E-ISSN 2716-070X

Jurnal ABDIMAS Vol. 2,No.3,Agustus 2021,Hal(18- 25)

@Prodi Manajemen Fakultas Ekonomi Universitas Pamulang

Email: abdimasjurnal.unpam@ gmail.com Telp: (021) 741-2566 bijak dan sisihkan sebagian untuk memperbesar perusahaan.

Keberhasilan bisnis tidak hanya ditentukan oleh kemampuan menjual, melainkan juga mengatur keuangan.

\section{METODE PELAKSANAAN}

Adapun tempat dan waktu pelaksanaan kegiatan Pengabdian Kepada Masyarakat ini di lakukan di UKM Merta Yasa, Desa Blega Kabupaten Gianyar, Bali terhitung tanggal 5 7 Maret 2021 dengan rangkaian kegiatan sebagai berikut:

\section{Pelaksanaan Kegiatan}

Kegiatan ini mengangkat tema "penyuluhan pengelolaan keuangan usaha kecil menengah pada ukm merta yasa, baliee .

Tema tersebut diatas diambil berdasarkan hasil dari rapat PKM yang dilakukan dengan seksama di antara para dosen dengan hasil tinjauan terhadap situasi dan kondisi di Lokasi PKM . Kegiatan ini berupa memberikan materi dan simulasi bagaimana Pengelolaan Keuangan Pada UKM Merta Yasa Guna Meminimalisir Pengeluaran.

\section{Tahap Persiapan}

Tahap persiapan kegiatan PKM yang dilakukan melipui:

a. Survei awal, pada tahap ini dilakukan pemantapan dan penentuan lokasi dan sasaran.

b. Pengajuan proposal ke Desa Blega \& Universitas Pamulang

c. Penyusunan bahan/materi pelatihan, yaitu meliputi slide dan makalah tentang tema PKM.

\section{Tahap Pelaksanaan Pelatihan}

Pelatihan diadakan dengan mengusulkan materi Penyuluhan Pengelolaan Keuangan Usaha Kecil Menengah Pada Ukm Merta Yasa, Bali. Kegiatan ini dilakukan melalui jadwal dan schedule yang sistematis dan setiap pergantian materi diselingi dengan ice breaking dan tanya jawab serta pemutaran Video. Selanjutnya peserta berkumpul bersama tim PKM untuk melakukan sharing session tentang tema yang dibahas.

\section{Metode Kegiatan}

Dalam melaksanakan kegiatan PKM ini digunakan beberapa metode yaitu:

1. Metode Ceramah / Presentasi, Metode ceramah/presentasi dipilih untuk memberikan penjelasan mengenai:

a. Memberikan pengetahuan terkait dengan memanajemen keuangan UKM yang baik dan benar

b. Memberikan pengetahuan terkait dengan cara meminimalisir pengeluaragan keuangan UKM secara efektif

c. Memberikan pengetahuan terkait dengan pengelolaan keuangan UKM.

2. Metode Tanya Jawab

Metode Tanya jawab sangat penting bagi para peserta. Metode ini memungkinkan para pengusaha UKM menggali pengetahuan sebanyak-banyaknya tentang Pentingnya Manajemen Keuangan UKM di desa Blega.

3. Sharing Session. Tentang Pentingnya Manajemen Keuangan UKM Pada UKM Merta Yasa guna Meminimalisir Pengeluaran.

\section{HASIL DAN PEMBAHASAN}

Untuk mengefektifkan berbagai fungsi dalam manajemen keuangan bisnis, terdapat tugas administrasi yang sebaiknya dilaksanakan oleh para pelaku UMKM. Ketertiban pencatatan administrasi juga sangat bermanfaat sebagai salah satu alat perencanaan pengembangan bisnis. Beberapa kegiatan yang perlu dilaksanakan oleh para pelaku UMKM adalah sebagai berikut:

1. Administrasi piutang, merupakan catatan yang penting sebagai informasi internal dan eksternal.

2. Administrasi utang, merupakan kewajiban pebisnis kepada pihak eksternal. Pencatatan utang bisnis sama pentingnya dengan piutang. Laporan tentang posisi utang akan memberikan peringatan kepada para pelaku bisnis untuk melakukan berbagai langkah antisipasi terhadap kemungkinan munculnya kesulitan keuangan UMKM dalam membayarkan kembali 


\section{JURNAL ABDIMAS

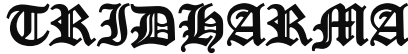 AtA:}

P-ISSN 2615-6849, E-ISSN 2716-070X

Jurnal ABDIMAS Vol. 2,No.3,Agustus 2021,Hal(18- 25)

@Prodi Manajemen Fakultas Ekonomi Universitas Pamulang

Email: abdimasjurnal.unpam@ gmail.com Telp: (021) 741-2566 utangnya.

3. Administrasi persediaan, memiliki peran yang strategis baik bisnis yang bergerak di bidang perdagangan maupun bisnis manufaktur.

4. Administrasi aset tetap, berfungsi untuk menunjukkan kapan suatu barang dibeli. Serta bagaimana menentukan tingkat penyusutan dan mulai berlakunya, serta waktu berakhirnya.

5. Administrasi kas, berguna dalam memberikan informasi tentang berapa jumlah uang kas yang masuk dan kas yang keluar. Sehingga keseimbangan antara penerimaan dan pengeluaran dapat terjaga.

6. Administrasi penggajian, merupakan bagian dari manajemen personalia yang juga sebagai dasar dalam perhitungan pajak. Manfaat lainnya adalah untuk menjaga keseimbangan antara perubahan yang terjadi di lingkungan bisnis yang sehubungan dengan kinerja karyawan.

\section{Tips Mengelola Keuangan UKM}

Keuangan merupakan jantung bagi setiap bisnis jenis apapun. Karena setiap pergerakan dalam bisnis selalu ditinjau dari segi finansial. Manajemen keuangan sangat menentukan langkah kedepan yang harus diambil oleh para pelaku bisnis. Oleh karena itu, penting bagi Anda untuk mengelola keuangan dengan baik dan benar. Sehingga keuangan bisnis dapat dikendalikan dengan baik. Berikut ini adalah beberapa tips mengelola keuangan dalam UMKM:

1. Memisahkan uang pribadi dengan uang bisnis.

2. Menganggarkan pengeluaran dengan sebijak mungkin. Hindarilah pengeluaran yang tidak penting bagi kemajuan bisnis, dan buatlah daftar prioritas kebutuhan serta anggarkan terlebih dulu hal mana yang menentukan perkembangan bisnis.

3. Mencatat semua transaksi keuangan bisnis. Siapkan sebuah buku khusus untuk mencatat setiap transaksi keuangan yang terjadi di dalam bisnis. Catatlah semua transaksi dan aliran keuangan yang terjadi ke dalam formulir, kemudian disalin ke dalam buku keuangan.

4. Mengontrol dan mengawasi arus kas bisnis.

5. Menyediakan dana cadangan. Persiapkan dana untuk menghadapi keadaan darurat dengan cara memperkirakan masalah-masalah yang kemungkinan harus dihadapi pada saat menjalankan bisnis. Setelah itu, tentukan jumlah nilai dari dana cadangan tersebut. Sehingga hal ini dapat mengurangi dampak dari masalah yang datang secara tiba-tiba.

\section{KESIMPULAN DAN SARAN \\ Kesimpulan}

Dari kegiatan pengabdian pada masyarakat ini dapat disimpulkan bahwa dalam memulai usaha diawali dengan memahami pengertian UKM, untuk dapat mengembangkannya dengan peluang dan dukungan Pemerintah. Tiap usaha perlu menyiapkan modal, produk, dan strategi pemasaran yang detail. Hal-hal tersebut memastikan keberhasilan usaha yang sukses dan berkelanjutan.

Lakukan juga proses pembukuan pada usaha yang tengah dibangun. Dengan pembukuan yang baik, dapat dengan mudah memantau keseluruhan arus keuangan dan transaksi yang telah terjadi. Untuk memudahkan proses pembukuan dan memudahkan dalam membuat perancanaan bisnis yang lebih baik, dan juga pengusaha UKM bisa mencoba menggunakan software akuntansi berbasis cloud agar bisa digunakan kapan pun dan dimanapun.

\section{Saran}

Mengingat besarnya manfaat kegiatan pengabdian pada masyarakat ini, maka selanjutnya perlu:

1. Mengadakan sosialisasi dan pelatihan 


\section{JURNAL ABDIMAS

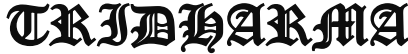

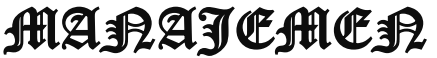

P-ISSN 2615-6849, E-ISSN 2716-070X

Jurnal ABDIMAS Vol. 2,No.3,Agustus 2021,Hal(18- 25)

@Prodi Manajemen Fakultas Ekonomi Universitas Pamulang

Email: abdimasjurnal.unpam@ gmail.com Telp: (021) 741-2566 serupa pada pengusaha UKM lain di kabupaten yang lain, dengan materi yang serupa.

2. Adanya kesinambungan program pasca kegiatan pengabdian ini sehingga para pengusaha UKM benarbenar dapat mengembangkan kemampuannya dalam membuat perencanaan keuangan.

\section{DAFTAR PUSTAKA}

Diyana, Ita Yustian Free. 2017. Analisis Pengelolaan Keuangan Pada Usaha Mikro Kecil dan Menengah Studi Kasus Pada Asosiasi Batik Mukti Manunggal Kabupaten Sleman. Universitas Sanata Dharma, Yogyakarta

Gitman, Lawrence, J.(2015). Principles of Manajerial Finance. International Edition, 10th edition, Pearson Education, Baston.

Hasibuan, Malayu S.P. (2012). Manajemen Sumber Daya Manusia. Jakarta : PT.Bumi Aksara.

Hartati, Sri. 2013. Manajemen Keuangan Untuk Usaha Mikro, Kecil Dan Menengah. $\quad$ www.apipwu.com/wpcontent/uploads/2013/01/Art ikelSri-Hartati.pdf

Hasyim, Diana. 2013. Kualitas Manajemen Keuangan Usaha Mikro Kecil Menengah (UMKM) (Studi Kasus Pada Distribution Store (Distro) Di Kota Medan). JUPIIS VOLUME 5 Nomor 2, Desember 2013

Kasmir (2010) , Pengantar Manajemen Keuangan. Edisi Kedua, Penerbit: Kencana Prenada Media Group, Jakarta.

Artikel Perkembangan Jumlah Umkm Di Indonesia Tahun 2017, (Https://www.Lisubisnis.Com/2016/12/Pe rkembangan-JumlahUmkm-DiIndonesia.Html )

Badan Pusat Statistik Kabupaten Ponorogo. 2017. Kabupaten Ponorogo Dalam Angka
2017. Ponorogo: BPS Kabupaten Ponorogo

Hulasoh, E., Syamsuddin, R. A., Praditya, A., Lisdawati, \& Supardi. (2020). Pengaruh Gadget Terhadap Prestasi Belajar Remaja Di Era Milenial Pada Lembaga Bimbingan Belajar Daarul 'Uluum Petukangan Utara, Pesanggrahan, Jakarta Selatan. ABDIMAS.

Pratama, A., \& Syamsuddin, R. A. (2020). DAMPAK KOMITMEN ORGANISASI ATAS KINERJA KARYAWAN PT BNI KCP PAMULANG. ProBank. https://doi.org/10.36587/probank.v5i2.72 3

Pasaribu, V. L. D., Agrasadya, A., Shabrina, N., \& Krisnaldy, K. (2020). Menjadi Enterpreneur Muda Yang Memiliki Jiwa Leadership Untuk Menghadapi Masa Depan. Abdi Laksana: Jurnal Pengabdian Kepada Masyarakat, 1(1).

Pasaribu, V. L. D., Susanti, F., \& Hartuti, E. T. K. (2019). Memotivasi Siswa dan Siswi SMK Letris Indonesia di Dalam Menentukan Pilihan Untuk Melanjutkan Pendidikan Atau Bekerja Setelah Lulus Sekolah. Jurnal Pengabdian Dharma Laksana, 1(2), 161-172.

Pasaribu, V. L. D., Sulaiman, S., Sutiman, S., Thaharudin, T., \& Purnomo, B. Y. (2020). Pengenalan Letak Posyandu Terdekat Dikelurahan Pisangan Dengan Manajemen Pemasaran Revolusi 4.0 Untuk Meningkatkan Pengetahuan Masyarakat Letak Dan Fungsi Posyandu Terdekat Pada Kelurahan Pisangan. Dedikasi Pkm, 1(1), 105-110.

Pasaribu, V. L. D., Oktrima, B., Prabowo, B., 


\section{JURNAL ABDIMAS

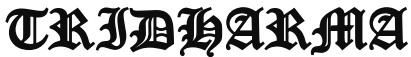

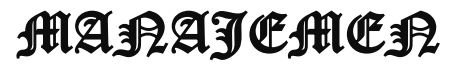

Arianto, N., \& Haryoko, U. B. (2020). Progam Pendampingan Dan Penyelenggaraan Pendidikan Anak Pada Usia Dini Terhadap Prestasi Belajar Dilingkungan Rt 020 Rw 009. Kel Giri Peni. Kec Wates. Yogyakarta. Jurnal Lokabmas Kreatif, 1(1), 71-75.

Pasaribu, V. L. D., Jannah, M., Fazar, M., Putra, S. P., Monalisa, M., \& Sofa, M. (2021). MENINGKATKAN PRODUKTIVITAS USAHA DIMASA PANDEMI PADA IBU PKK RT 004/003 KELURAHAN SAWAH BARU CIPUTAT, TANGERANG SELATAN. Abdi Laksana: Jurnal Pengabdian Kepada Masyarakat, 2(2), 295-301.

Pasaribu, V. L. D., Yuniati, H. L., Pranata, R., Sembayu, R., Purba, S. M., \& Nurbayani, T. T. A. (2021). MANAJEMEN KEUANGAN UNTUK MENGHADAPI DAN BERTAHAN DI ERA COVID 19. Jurnal Abdimas Tri Dharma Manajemen, 2(2), 12-18.

Pasaribu, V. L. D., Dwiyatni, A., Sabina, C., Ridwan, M., Gunawan, D. D., \&

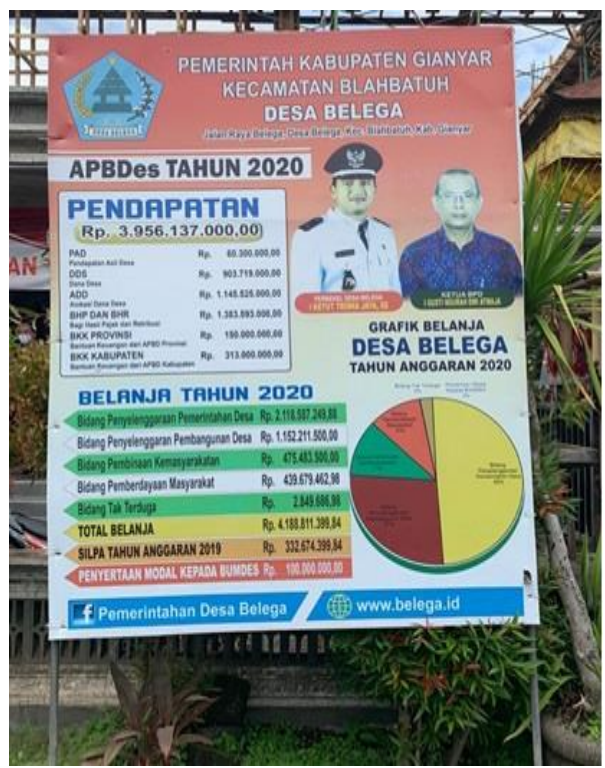

Noviani, B. C. (2021). EVALUASI PENERAPAN 3M DIMASA PANDEMIC COVID 19. Jurnal Abdimas Tri Dharma Manajemen, 2(2), 54-60.

Pasaribu, V. L. D., Syafei, A. N., Farhan, A., Aufaizah, A., Irani, C., \& Firtiayani, S. R. (2021). PENGARUH DISPLIN PROTOKOL KESEHATAN TERHADAP PENCEGAHAN PENULARAN VIRUS COVID19. Jurnal Abdimas Tri Dharma Manajemen, 2(2), 91-98.

Priadi, A., Pasaribu, V. L. D., Virby, S., Sairin, S., \& Wardani, W. G. (2020). Penguatan Ekonomi Kreatif Berbasis Sumber Daya Desa Dikelurahan Rempoa. Abdi Laksana: Jurnal Pengabdian Kepada Masyarakat, 1(3), 356-35

\section{FOTO KEGIATAN}
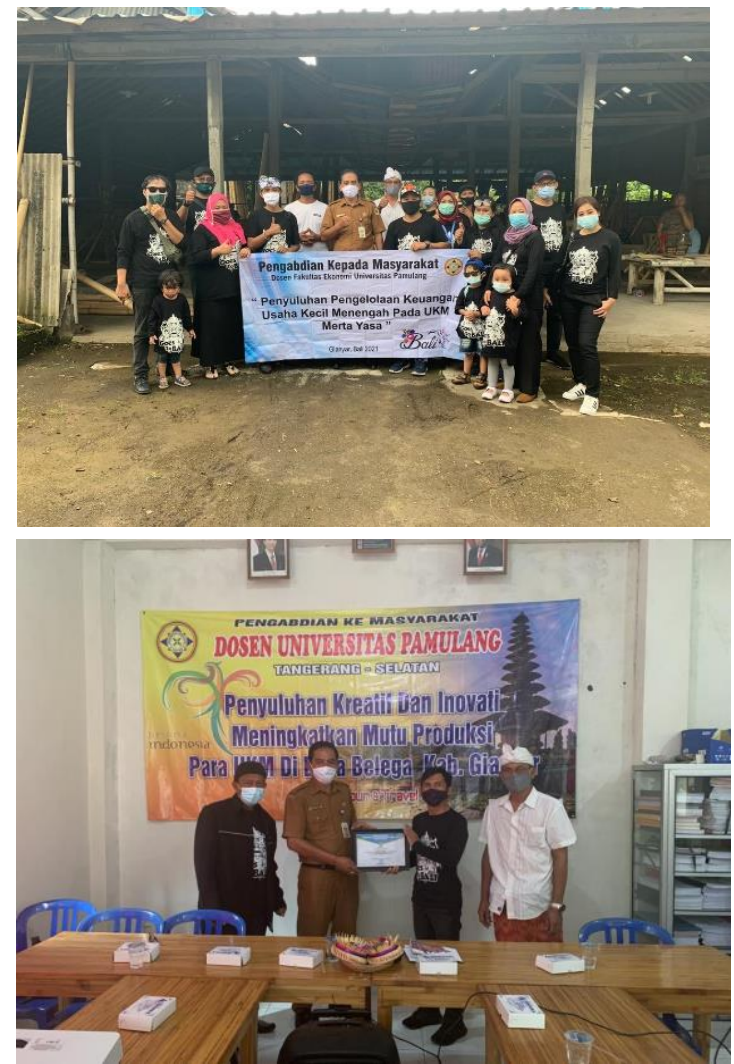